\title{
PERSEPSI MASYARAKAT TERHADAP HARGA JUAL KOPRA DI DESA LORWEMBUN KECAMATAN KORMOMOLIN KEPULAUAN TANIMBAR
}

\author{
Mihel Tuatfaru \\ Dosen Sekolah Tinggi Ilmu Ekonomi Saumlaki, miheltuatfaru15@gmail.com
}

\begin{abstract}
Abstrak
Persepsi merupakan salah satu proses yang didahului melalui Rangsangan yang diterima, diseleksi, diorganisir dan diinterprestasikan informasinya. Presepsi tidak hanya tergantung pada rangsangan fisik tetapi juga rangsangan yang berhubungan dengan lingkungan disekitarnya dan keadaan individu yang bersangkutan. Dalam ilmu ekonomi, perkembangan teori produksi ini sama rumusnya dengan perkembangan ilmu ekonomi itu sendiri. Hal ini dalam aktifitas ekonomi pada umumnya yang paling sering dilakukan adalah aktifitas kompleks. Kegiatan produksinya sendiri sebenarnya merupakan kegiatan yang lahir bersama dengan lahirnya kebutuhan manusia, maka diperlukan suatu proses produksi untuk memenuhinya, baik secara sub sistem maupun modern. Penelitian ini dilakukan dengan tujuan untuk mengetahui seberapa besar presepsi masyarakat terhadap harga jual kopra.
\end{abstract}

Kata Kunci : Presepsi Masyarakat, Harga Jual, Kopra.

\section{PENDAHULUAN}

Setiap negara memiliki rencana pembangunan sesuai degan programnya masing-masing dan kemampuan perekonomiannya. Pembangunan secara menyeluruh di berbagai bidang merupakan suatu rencana bagi setiap negara, terutama di berbagai negara yang sedang

berkembang dalam upaya mewujudkan tujuan atau cita-cita yang akan dicapai.

Penduduk bertambah dari waktu ke waktu dapat menjadi pendorong maupun penghambat bagi perkembngan 
perekonomian penduduk yang bertambah akan memperbesar jumlah tenaga kerja dan penambahan tersebut memungkinkan negara itu menambah produksi akan suatu barang dan jasa. Dorongan lain yang timbul dari perkembangan penduduk terhadap pertumbuhan ekonomi bersumber dari akibat pertumbuhan itu kepada luas pasar. Perkembangan penduduk menyebabkan besarnya luas pasar dari barang-barang yang dihasilkan dari sektor industri/perusahaan, karena peranan ini maka perkembangan penduduk akan menimbulkan dorongan kepada pertumbuhan dalam produksi dalam suatu kegiatan ekonomi.

Dalam era pembagunan nasional, pembangunan yang dilaksanakan di Indonesia secara bertahap, terencana dan berkesinambungan, setiap tahapan dari pembangunan yang ada bertujuan untuk meningkatkan taraf hidup dan kesejahteraan masyarakat serta meletakkan landasan yang kokoh untuk pembangunan berikutnya. Salah satu bidang pembangunan yang memberikan aspek perencanaan terhadap tujuan diatas adalah bidang ekonomi.

Pembangunan nasional menitik beratkan pada sektor pertanian dan selanjutnya pembangunan pertanian bertujuan meningkatkan mutu dan hasil produksi, meningkatkan pendapatan dan taraf hidup petani, memperluas lapangan kerja serta kesempatan kerja untuk menunjang pembangunan industri maupun meningkatkan ekspor. Konsep pembangunan yang dikemukakan diatas mengandung arti bahwa pembangunan pedesaan mendapatkan perhatian yang cukup serius, sebab pembangunan pedesaan merupakan pembangunan yang dilakukan di wilayah pemerintah terendah dengan sasaran utama adalah untuk meningkatkan taraf hidup masyarakat.

Berkaitan dengan hal diatas maka Mubyarto (1983;43) mengemukakan bahwa: "Pembangunan Nasional menitikberatkan pada sektor pertanian dan selanjutnya pembangunan pertanian bertujuan meningkatkan mutu dan hasil produksi, meningkatkan pendapatan dan taraf hidup petani, memperluas lapangan pekerjaan serta kesempatan kerja untuk menunjang pembangunan industri maupun meningkatkan eksport."

Pertumbuhan ekonomi sebagai hasil dari pembangunan harus dapat menciptakan suasana kehidupan masyarakat yang adil dan makmur. Kondisi perekonomian yang 
terjadi saat ini akan berlanjut pada masa yang akan datang dan telah membawa perubahan yang mendasar dalam kehidupan masyarakat. Hal ini merupakan kesempatan sekaligus tantangan bagi masyarakat. Dengan demikian sangat diharapkan dengan adanya pembangunan pertanian dapat meningkatkan hasil produksi pertanian dan sekaligus meningkatkan pendapatan petani.

Penentuan harga jual merupakan salah satu kebijakan yang penting dalam perusahaan karena dengan penetapan harga jual yang benar akan dapat mempengaruhi volume penjualan dan laba yang didapat perusahaan. Dalam penentuan harga jual harus mempertimbangkan tujuan yang hendak dicapai dan faktor-faktor yang sulit diramalkan yang mempengaruhi pembentukan harga jual dan jasa.

Faktor-faktor tersebut antara lain permintaan konsumen atas suatu produk dan jasa, selera konsumen, jumlah pesaing yang ada di pasar dan harga jual yang ditentukan oleh pesaing. Salah satu yang memiliki kepastian relatif tinggi yang berpengaruh dalam penentuan harga jual adalah biaya, karena biaya memberikan informasi batas bahwa suatu harga harus ditentukan. Dalam penelitian ini disimpulkan bahwa didalam menentukan harga jual, perusahaan menentukanlaba yang di pedesaan yang lebih perhatiannya dalam meningkatkan pendapatan masyarakat dalam bidang pertanian.

\section{KAJIAN TEORI}

\section{Pengertian Persepsi}

Persepsi pada hakekatnya adalah proses kognitif yang dialami oleh setiap orang didalam memahami informasi tentang lingkungannya, baik lewat penglihatan, pendengaran, penghayatan perasaan dan penciuman (Miftah Thoha, 1983;138). Oleh sebab itu kunci untuk memahami persepsi adalah terletak pada pengenalan bahwa persepsi itu merupakan suatu penafsiran yang unik terhadap situasi dan bukannya suatu pencatatan yang benar terhadap situasi. Hal ini diperjelaskan lagi oleh Kroch yang mengatakan "bahwa persepsi adalah suatu proses kognitif yang kompleks dan menghasilkan suatu gambar unik tentang kenyataan yang barang kali sangat berbeda dari kenyataannya.

Selanjutnya Kotler (1997), mendefinisikan persepsi sebagai proses pemilih, menata, 
menafsirkan yang dilakukan seseorang agar mencapai arti tertentu, sedangkan pelayanan atau pengguna juga adalah orang yang menuntut orang lain untuk memenuhi standar tertentu karena yang dapat diberikan adalah pengaruh kinerja orang lain, atau dapat dikatakan bahwa pelanggan adalah orangyang tidak tergantung kepada orang lain yang memiliki produksi sendiri tetapi mereka mempunyai produk yang tergantung sepenuhnya kepada orang yang mau membeli produk tersebut.

\section{A. Proses Persepsi}

Persepsi setiap orang terhadap suatu objek yang berbeda-beda, oleh karena itu persepsi mempunyai sifat subyektif. Pembentukan persepsi yang terjadi dalam diri manusia diawali melalui panca indera. Michael R. Solomon menguraikan proses pembentukan persepsi dalam lima (5) proses yaitu:

\section{Stimuli}

Stimuli adalah setiap bentuk fisik, visual atau komunikasi verbal yang dapat mempengaruhi tanggapan individu. Stimuli dalam pemasaran dapat diperoleh melalui produk, iklan, toko dan pengaruh sales. Ketika stimulus mengenai alat indera ini merupakan proses yang bersifat fisik, kemudian rangsangan itu diteruskan kedalam otak oleh indera penerima terhadap stimuli dasar, yang akan membentuk perhatian seseorang pada sumber rangsangan.

\section{Perhatian}

Manusia dapat memperhatikan banyak objek sekaligus dalam suatu waktu dan sudah tentu tidak semua objek mendapatkan perhatian yang sama. Perhatian yang dilakukan oleh konsumen dapat terjadi secara sengaja atau tidak sengaja. Perhatian yang dilakukan sengaja disebut voluntary yaitu ketika konsumen secara aktif mencari informasi secara relevansi pribadi, sedangkan perhatian yang tidak sengaja itu terjadi ketika kepada konsumen dipaparkan sesuatu yang menarik, mengejutkan menentang atau sesuatu yang tidak diperkirakan yang tidak ada relevansinya dengan tujuan atau kepentingan konsumen, misalnya terjadi ketika konsumen menonton televisi di potong dengan iklan dan iklan tersebut mendapatkan perhatian yang tidak sengaja.

\section{Interpretation}

Interpretation adalah cara seseorang dalam membentuk suatu pengertian dirinya tentang suatua objek yang telah diperhatikan sebelumnya. 


\section{Respon}

Respon adalah reaksi atau tanggapan konsumen terhadap stimuli tertentu, sehingga memberikan kesan dalam diri seseorang setelah di terimanya hasil penginterpretasian yaitu berupa pengertian terhadap objek yang telah diperhatikan.

5. Persepsi

Persepsi merupakan proses yang didahului melalui penginderaan yang diterimanya stimuli kemudian rangsangan. Rangsangan yang diterima, diseleksi, diorganisir dan diinterprestasikan informasinya.

Presepsi tidak hanya tergantung pada rangsangan fisik tetapi juga rangsangan yang berhubungan dengan lingkungan disekitarnya dan keadaan individu yang bersangkutan. Kata kunci dalam defenisi presepsi adalah individu, orang dapat memiliki presepsi yang berbeda atau subjek yang sama karena tiga (3) proses presepsi yaitu:
a. Perhatian yang selektif.
b. Distori selektif.
c. Ingatan selektif.

\section{B. Teori Harga}

Harga dipakai oleh orang untuk mengukur nilai suatu barang atau jasa dengan dirupakan dengan uang. Harga memiliki kaitan yang erat dengan permintaan kaitannya itu sebagai berikut:

1. Jika harga naik karena kenaikan biaya produksi atau ada tambahan biaya lain, permintaan menjadi turun karena bnyak orang yang tidak mampu membeli.

2. Jika harga turun karena produksi menjadi lebih efisien atau ada biayabiaya yang bisa dihemati lebih banyak orang yang mampu membeli sehingga permintaan meningkat.

\section{Teori Produksi}

Masalah ekonomi timbul sebagai akibat dari tidak sesuainya jumlah barang dan jasa yang disediakan oleh para pengusaha di dalam memenuhi akan kebutuhan masyarakat yang ada, sehingga kapasitas jumlah permintaan itu selalu ada di dalam masyarakat.

Dilihat dari berbagai sudut pandang ahli ekonomi bahwa kegiatan manusia yang dilakukan untuk memenuhi kebutuhan hidupnya terdiri atas beberapa bagian, salah satu diantaranya yaitu kegiatan produksi. Dalam ilmu ekonomi, perkembangan teori produksi ini sama rumusnya dengan perkembangan ilmu ekonomi itu sendiri. Hal ini dalam aktifitas ekonomi pada umumnya yang paling sering dilakukan adalah aktifitas kompleks. 
Kegiatan produksinya sendiri sebenarnya merupakan kegiatan yang lahir bersama dengan lahirnya kebutuhan manusia, maka diperlukan suatu proses produksi untuk memenuhinya, baik secara sub sistem maupun modern.

\section{METODE PENELITIAN}

\section{A. Lokasi Penelitian}

Yang menjadi lokasi penelitian dalam penulisan skripsi ini adalah di Desa Lorwembun Kecamatan Kormomolin, Kabupaten Kepulauan Tanimbar.

\section{B. Populasi dan Sampel}

1. Populasi

Dalam penelitian ini yang menjadi populasi adalah masyarakat yang ada di Desa Lorwembun terkhusus bagi masyarakat petani kopra yang berjumlah 70 Kepala Keluarga.

2. Sampel

Menurut Djarwanto (1998;108) sampel adalah sebagian dari populasi yang karateristiknya hendak diselidiki dan dianggap bisa mewakili keseluruhan populasi. Mengingat jumlah populasi terlalu banyak sehingga teknik pengambilan yang digunakan dalam penelitian ini (sampling random) acak sederhana, dengan jumlah yang diteliti yaitu sebanyak 35 orang.

\section{Jenis dan Sumber Data}

\section{Jenis Data}

Jenis data yang digunakan dalam penelitian ini adalah meliputi:

a. Data kualintatif yaitu data yang diukur atau dihitung secara langsung berdasarkan angkaangka dari hasil penelitian yang bersumber dari hasil pengelolaan jawaban kuesioner dari responden.

b. Data kualitatif, yaitu data yang bersifat penggolongan, termasuk dalam kualifikasi yang berskala ukuran minimal dan ordinal.

\section{Sumber Data}

Data yang digunakan dalam penelitian ini bersumber dari;

a. Data Primer yaitu data hasil penelitian yang diperoleh melalui pengisian kuesioner, pelaksanaan dan pengamatan terhadap variabel penelitian.

b. Data Sekunder yaitu, data yang diperoleh dari studi kepustakaan dan 
dokumentasi yang meliputi sumbersumber hukum peraturan dan konsep mengenai variabel penelitian serta hubungan antara variabel.

\section{Teknik Pengambilan Data}

Pengumpulan data menggunakan metode angket, data dikumpulkan dengan cara menyebar daftar pertanyaan untuk mendapat data-data penilaian masyarakat tentang presepsi masyarakat terhadap harga jual kopra di Desa Watmuri Kecamatan Nirunmas Kabupaten Maluku Tenggara Barat.

1. Observasi yaitu mengadakan pengamatan secara langsung terhadap objek penelitian.

2. Daftar kuesioner.

3. Wawancara langsung yang dilakukan penulis terhadap seluruh responden.

\section{E. Teknik Analisa Data}

Alat analisa yang digunakan adalah analisa regresi linear sederhana yang secara matematis dapat ditulis sebagai berikut :

$$
\begin{aligned}
y & =a+b x, \text { dimana } \\
y & =\text { harga jual } \\
x & =\text { presepsi masyarakat } \\
a & =\text { costanta } \\
b & =\text { koefisien regresi }
\end{aligned}
$$

Selanjutnya menurut Sugiyono $(2007 ; 107)$ untuk mengukur sikap, pendapat dan presepsi seseorang atau sekelompok orang tentang fenomena sosial maka digunakan skala likert atas setiap jawanam pada item instrument yang dari positif sampai negatif yang dapat berupa.

\section{HASIL DAN PEMBAHASAN}

Dari analisis hasil penelitian dapat diketahui bahwa adanya presepsi baik dari masyarakat terhadap harga jual kopra di Desa Lorwembun. Hal ini dapat diketahui dari penjelasan indikator sebagai berikut:

Analisis presepsi masyarakat terhadap kerelaan menjual kopra sesuai dengan harga yang ada, diketahui bahwa rata-rata masyarakat bersedia untuk menjual kopra yang ditetapkan.

Analisia presepsi masyarakat terhadap harga yang ditetapkan sesuai dengan kebutuhannya sehari-hari, diketahui bahwa secara rata-rata beranggapan harga tersebut sudah sesuai dengan kebutuhan sehari-hari.

Analisis presepsi terhadap pertimbangan harga kopra untuk diturunkan diketahui ternyata bahwa memang rata-rata masyarakat tidak setuju untuk harga yang telah diberlakukan harus diturunkan. Hal 
ini berarti bahwa anggapan masyarakat terhadap harga yang ditetapkan oleh para pengusaha sudah selesai.

Analisis presepsi masyarakat terhadap kepuasan harga diketahui bahwa sebagian besar masyarakat beranggapan bahwa kepuasan harga sangat penting untuk melakukan penjualan kopra. Hal ini berarti bahwa kepuasan harga dianggap baik.

Analisis presepsi masyarakat terhadap harga jual yang ditetapkan sesuai dengan kebutuhan hidupnya sehari-hari, diketahui ternyata bahwa rata-rata masyarakat beranggapan bahwa kebutuhan hidupnya dapat terpenuhi sehari-hari.

\section{KESIMPULAN}

Berdasarkan hasil pembahasan dapat diambil beberapa kesimpulan diantaranya adalah sebagai berikut:

1. Berdasarkan hasil analisis, menunjukkan bahwa ada presepsi baik dari masyarakat terhadap harga jual kopra di Desa Lorwembun Kecamatan Kormomolin Kabupaten Kepulauan Tanimbar.

2. Harga jual kopra saat ini berdasarkan kesepakatan bersama oleh para pengusaha. Hal ini terjadi karena belum adanya harga jual kopra yang resmi dari Pemerintah Kabupaten Kepulauan Tanimbar.

\section{DAFTAR PUSTAKA}

Ari Sudarman.Teori Ekonomi Mikro. Jilid Pertama, Penerbit FE UGM. Yogyakarta, 1980.

Adam. S. Ekonomi SMA. Penerbit Erlangga, Jakarat. 2001.

Bishop \& W. D. Tousaint. Pengantar Analisa Ekonomi. Terjemahan, Wisnardji, 1987.

Budiono. Ekonomi Mikro. BPFE, Bandung. 2000.

Hermanto. Teori Ekonomi Makro. Penerbit Penelar Swadaya, Jakarta. 1989.

Miftah Thoha. Perilaku Organisasi, Konsep Dasar \& Aplikasinya. Penerbit CV. Rajawali, Jakarat. 1983.

Mulyanto. Pengantar Ekonomi Pertanian. Yogyakarta, 1997.

Sugiyono. Metode Penelitian Administrasi. Edisi ke 15. Penerbit CV. Aljabeta, Bandung. 2007.

Sudarsono. Pengantar Ekonomi Makro. Cetakan Pertama. Penerbit Lembaga Pemilihan Pendidikan \& Penerangan Ekonomi, Jakarta. 1983. 